\title{
Concomitant psychiatric symptoms and impaired quality of life in women with cervical cancer: a critical review
}

This article was published in the following Dove Press journal:

International Journal of Women's Health

30 October 2017

Number of times this article has been viewed

\author{
Stephanie Klügel' \\ Caroline Lücke' \\ Aurora Meta' \\ Meike Schild-Suhren ${ }^{2}$ \\ Eduard Malik ${ }^{2}$ \\ Alexandra Philipsen' \\ Helge HO Müller ${ }^{1,3}$ \\ 'Department of Psychiatry and \\ Psychotherapy, Carl von Ossietzky \\ University Oldenburg, Bad \\ Zwischenahn, ${ }^{2}$ Department of \\ Gynecology and Obstetrics, Carl \\ von Ossietzky University Oldenburg, \\ Oldenburg, ${ }^{3}$ Friedrich-Alexander \\ University Erlangen-Nuremberg, \\ Erlangen, Germany
}

Abstract: Our aim was to summarize the current relevant literature on concomitant psychiatric symptoms with a focus on anxiety/depression in a population with gynecologic cancer; to identify the predictors, associated factors, and prevention strategies of psychiatric disorders; to examine psychiatric disorders in a population with recurrent gynecologic cancer; and to describe the limitations of the literature and future research areas. Little is known about attending psychiatric disorders in patients with gynecologic and other malignant diseases like cervical or breast cancer. However, patients suffering from other types of gynecologic cancer (eg, genital/ cervical cancer) may also have an increased risk of psychiatric symptoms. In this review, we identify the potential information deficits in this field. A two-rater independent literature search was conducted using the PubMed/Google Scholar search engines to systematically evaluate the literature on the research objectives, followed by a critical reflection on the results. Of the 77 screened studies, 15 met the criteria for inclusion in this review. Patients with gynecologic malignancies, especially cervical cancer, had a very high prevalence of psychiatric symptoms including depression (33\%-52\%). Additionally, the risk groups facing higher rates of concomitant reduced quality of life and increased psychiatric symptoms such as depression were identified. Specifically, low socioeconomic status, sexual inactivity, absence of a partner, and physical symptoms were correlated with an increased risk. Patients suffering from recurrent gynecologic cancer should receive particular attention because of their significantly increased risk of depressive symptoms. Screening programs are needed to detect psychiatric symptoms in cervical cancer patients and the associated high-risk groups. Regular screening should be implemented, and psychosocial care should be provided during follow-up.

Keywords: gynecologic cancer, comorbidity, psychiatric disorders, depression, coping, resilience

\section{Introduction}

Mental disorders, defined as specific impairments in domains such as affect, perception, and (social) interaction, are common diseases. Somatic and/or social stressors impact the functioning of mental and physiological systems, which are attuned to complex interactions among social, cultural, and interactional factors. In the European Study of the Epidemiology of Mental Disorders, $14 \%$ of the general European population reported a lifetime history of some type of mood disorder and $13.6 \%$ reported a lifetime history of anxiety. ${ }^{1}$ Probands with somatic diseases such as cancer are known to be at risk of concomitant psychiatric symptoms such as depression and anxiety, as well as reduced quality of life $(\mathrm{QoL})$. In the general cancer population, the prevalence of depression ranges from $8 \%-24 \%$ (depending on the type of instrument used, the type of cancer, and the treatment phase). ${ }^{2}$ There is a significant overlap between
Correspondence: Helge HO Müller Department of Psychiatry and Psychotherapy, Carl von Ossietzky University Oldenburg, HerrmannEhlersstrasse 7, D-26I60 Bad

Zwischenahn, Germany

Tel +49 44I 96I5 I507

Email helge.mueller I@uni-oldenburg.de 
psychiatric symptoms and cancer with somatic symptoms such as fatigue, pain, poor sleep, and concentration. . $^{3,4}$ Breast cancer is the most common malignant disease in women, with 458,000 affected women in Europe for an agestandardized incidence of 71 per 100,000 women and high mortality (16 per 100,000 European women). In addition, the mortality from this malignancy is higher than that from any other cancer. ${ }^{5}$ Breast cancer is also the type of cancer in which concomitant psychiatric symptoms such as anxiety/ depression, impaired QoL, and psychosocial impairments have been studied the most. ${ }^{6,7}$ According to systematic reviews and meta-analyses, the prevalence of depression in breast cancer patients ranges from $20 \%$ to over $50 \%$, which is much higher than the rate in the normal population. ${ }^{8-11}$ Indeed, studies have postulated that women with breast cancer may have an increased risk of depression. ${ }^{12-14}$ The therapeutic approach to breast cancer is based on a large body of evidence, ${ }^{15-18}$ and there is increasing interest but still very limited data regarding attending psychiatric diseases in female patients with gynecologic, genital, and cervical cancer. ${ }^{19-21}$ Patients suffering from different types of gynecologic cancer (genital/cervical cancer) may also have an increased risk of developing an attending psychiatric disease, but little is known about attending psychiatric disorders in patients with cancers other than breast cancer, such as gynecologic cancer.

In total, 185,000 women in Europe newly develop genital/ cervical cancer each year. ${ }^{22-24}$ Therefore, with disparities between ethnic and geographical regions, cervical cancer is the most common genital malignancy in women worldwide, with an incidence of 500,000 cases/year and a very high mortality of at least 300,000 deaths/year. ${ }^{25-27}$

Therefore, the aim of this mini-review, which was based on a current literature search, was to investigate the current knowledge on attending psychiatric disorders in a group of women with gynecologic cancer.

Cervical cancer does not initially cause pain, and only occasional spotting is reported. Because of these lack of symptoms, it is rarely detected in the early stage. ${ }^{26}$ From the moment the cancer is diagnosed, treatment for cervical cancer includes multiple modalities such as surgery, chemotherapy, and radiation and leads to changes in the affected woman. These patients may experience difficulties with changes in hormonal and sexual function (sexual inactivity or loss of sexual desire). Some patients may even repress their desire to have children due to a cervical cancer diagnosis. ${ }^{27}$

Considering these changes, it is not surprising that gynecologic cancer patients suffer from psychosocial restrictions. However, whether these restrictions are part of the disease itself or whether they are caused by therapy remains unknown. Regardless, the treatment for gynecologic malignancies focuses on the (physical) prolongation of life. Although studies have fortunately begun to focus on the QoL of affected female patients, ${ }^{28}$ little is known about these patients' mechanisms of managing the disease (coping) or their resilience (among other aspects).

Finally, when considering other cancers, psychiatric symptoms such as depression and anxiety are one of the most prevalent cancer-related symptoms. The existence of these psychiatric disorders likely influences the prognosis of the underlying disease by affecting the patient's QoL or the success of the therapy. ${ }^{29}$ To address these objectives, we closely examined the incidence of attending psychiatric disorders in patients with different types of gynecologic cancer, especially cervical cancer, in comparison with the incidence in general cancer patients. We hope to identify possible gaps in the literature. Furthermore, the findings should provide a foundation for future research in this field and should enhance the understanding of the psychosocial situation of women with gynecologic malignancies.

In conclusion, the central objectives that motivated this paper were as follows:

1) to summarize the relevant literature on attending psychiatric disorders in a gynecologic cancer population;

2) to identify the predictors, associated factors, and prevention strategies of psychiatric disorders;

3) to present the current knowledge on psychiatric symptoms in a population with recurrent gynecologic cancer;

4) to describe the limitations of the literature and identify future research areas; and

5) to enhance the development and implementation of earlier and better diagnoses in the long term.

\section{Methods}

In this review, we systematically identified and evaluated the literature concerning our research questions. We used the search engines PubMed and Google Scholar to identify relevant publications. Our search included the keywords "gynecologic cancer", "genital/cervical cancer", “cervical cancer", "psychiatric disorders", “depression", "anxiety", "quality of life", "coping", "recurrence", and "resilience" in different combinations. The references of the chosen publications were also examined to identify additional relevant studies.

This web-based literature search was conducted independently by two of the authors (HHOM, SK) in December 2016 
and January 2017. The exclusion/inclusion criteria and selected publications were determined by all of the other authors according to the Cochrane recommendations and with regard to the relevance of the literature to the topic of this mini-review.

In total, 106 studies that matched the screening criteria were evaluated, and the studies reported in this review were selected from this initial sample. The studies were evaluated individually and comparatively among themselves or in the context of the current literature.

The studies provided different observations and reports of attending psychiatric disorders in gynecologic cancer patients with a primary focus on including studies with female genital/cervical cancer patients. The publication period of all studies was 1992-2016. These publications predominantly utilized prospective questionnaire-based methods (either self-administered or interviewer-administered) and are also discussed from that methodological perspective. An overview of relevant studies is provided in Tables 1 and 2.

\section{Presentation of literature and results}

Overview of papers dealing with the occurrence, predictors/ associated factors and prevention strategies of concomitant psychiatric disorders.

\section{Results}

\section{Occurrence of psychiatric disorders}

We closely examined the prevalence of depression and anxiety disorders in cervical cancer patients and then compared these results with the prevalence in other types of gynecologic cancer. Next, other components such as QoL, self-esteem/self-confidence, and coping mechanisms were evaluated.

In terms of depression and anxiety as attending psychiatric symptoms in patients with cervical cancer, most of the studies showed comparable results.

In 1992, Corney et al examined 138 women with cancer of the cervix and vulva to gain insight into their psychosocial adjustment after major gynecological surgery. ${ }^{30}$ These authors used the Hospital Anxiety and Depression

Table I Overview of papers dealing with occurrence, predictors/associated factors, and prevention strategies of attending psychiatric disorders

\begin{tabular}{|c|c|c|c|c|c|}
\hline Authors & Year & Question & Design & Methods & Results \\
\hline Corney et $\mathrm{al}^{30}$ & 1992 & $\begin{array}{l}\text { Psychosocial adjustment } \\
\text { following major } \\
\text { gynecological surgery for } \\
\text { carcinoma of the cervix } \\
\text { and vulva }\end{array}$ & $\begin{array}{l}\text { Prospective, } \\
\text { cross-sectional }\end{array}$ & $\begin{array}{l}\text { Interviews to elicit post- } \\
\text { operative psychosocial and } \\
\text { psychosexual problems (HADS) }\end{array}$ & $\begin{array}{l}\text { Responses to the HADS indicated that } \\
20 \% \text { of the women were "probable" } \\
\text { cases of anxiety and } 21 \% \text { were "definite" } \\
\text { cases. On the depression scale, } 18 \% \\
\text { were "doubtful" cases and } 14 \% \text { were } \\
\text { "definite" cases. Two thirds of the } \\
\text { women were sexually active prior }\end{array}$ \\
\hline Cull et $\mathrm{al}^{35}$ & 1993 & $\begin{array}{l}\text { Early stage cervical cancer: } \\
\text { psychosocial and sexual } \\
\text { outcomes of treatment }\end{array}$ & $\begin{array}{l}\text { Prospective, } \\
\text { cross-sectional }\end{array}$ & $\begin{array}{l}\text { Self-reported questionnaires, } \\
\text { semi-structured interviews }\end{array}$ & $\begin{array}{l}\text { Mean scores for anxiety and depression } \\
\text { were higher than general population } \\
\text { means, and this sample scored higher } \\
\text { for psychological distress than disease- } \\
\text { free cancer patients, as indicated by } \\
\text { published data }\end{array}$ \\
\hline Lau et $\mathrm{a}^{36}$ & 2013 & $\begin{array}{l}\text { Psychiatric morbidity in } \\
\text { Chinese women after } \\
\text { cervical cancer treatment }\end{array}$ & $\begin{array}{l}\text { Prospective, } \\
\text { cross-sectional }\end{array}$ & $\begin{array}{l}\text { Cross-sectional study, } \\
\text { interviews with Chinese } \\
\text { bilingual SCID-I/P }\end{array}$ & $\begin{array}{l}\text { Psychiatric disorders, predominantly } \\
\text { depressive and anxiety disorders, are } \\
\text { common in Chinese cervical cancer } \\
\text { survivors }\end{array}$ \\
\hline Kim et $\mathrm{al}^{31}$ & 2010 & $\begin{array}{l}\text { Prevalence and predictors } \\
\text { of anxiety and depression } \\
\text { among cervical cancer } \\
\text { survivors in Korea }\end{array}$ & $\begin{array}{l}\text { Prospective, } \\
\text { cross-sectional }\end{array}$ & $\begin{array}{l}\text { HADS, EORTC QLQ-C30, } \\
\text { and the McGill QoL - } \\
\text { Questionnaire }\end{array}$ & $\begin{array}{l}\text { Cervical cancer survivors showed } \\
\text { relatively good mental health compared } \\
\text { with healthy controls; however, women } \\
\text { who have low functioning and well-being } \\
\text { could be at high risk of anxiety or } \\
\text { depression or both }\end{array}$ \\
\hline Yang et $\mathrm{al}^{32}$ & 2014 & $\begin{array}{l}\text { Prevalence and associated } \\
\text { positive psychological } \\
\text { variables of depression } \\
\text { and anxiety among } \\
\text { Chinese cervical cancer } \\
\text { patients }\end{array}$ & $\begin{array}{l}\text { Prospective, } \\
\text { cross-sectional }\end{array}$ & $\begin{array}{l}\text { Questionnaires (HADS, Herth } \\
\text { Hope Index, Life Orientation } \\
\text { Scale-Revised, General Self- } \\
\text { Efficacy Scale) }\end{array}$ & $\begin{array}{l}\text { The prevalence of depression and } \\
\text { anxiety were } 52.2 \% \text { and } 65.6 \% \text { in } \\
\text { cervical cancer patients. The anxiety } \\
\text { score was significantly higher in patients } \\
\text { from } 4-6 \text { months after diagnosis and at } \\
\text { cancer stage II }\end{array}$ \\
\hline
\end{tabular}

(Continued) 
Table I (Continued)

\begin{tabular}{|c|c|c|c|c|c|}
\hline Authors & Year & Question & Design & Methods & Results \\
\hline Klee et $\mathrm{al}^{33}$ & 2000 & $\begin{array}{l}\text { Life after radiotherapy: } \\
\text { the psychological and } \\
\text { social effects experienced } \\
\text { by women treated for } \\
\text { advanced stages of cervical } \\
\text { cancer }\end{array}$ & $\begin{array}{l}\text { Prospective, } \\
\text { cross-sectional }\end{array}$ & $\begin{array}{l}\text { EORTC QLQ-C30 and } \\
\text { additional specific questions }\end{array}$ & $\begin{array}{l}\text { Many patients experienced psychological } \\
\text { and social consequences at the end } \\
\text { of treatment and at I-3 months after } \\
\text { treatment. Patients continued to think } \\
\text { about their illness and treatment } \\
\text { throughout the 24-month study period } \\
\text { but found it increasingly hard to share } \\
\text { their worries with others. Their scores } \\
\text { for overall quality of life never reached } \\
\text { those of the controls }\end{array}$ \\
\hline Bradley et $\mathrm{al}^{34}$ & 2006 & $\begin{array}{l}\text { Quality of life and mental } \\
\text { health in cervical and } \\
\text { endometrial cancer } \\
\text { survivors }\end{array}$ & $\begin{array}{l}\text { Prospective, } \\
\text { cross-sectional }\end{array}$ & $\begin{array}{l}\text { Quality of life, mood, and } \\
\text { demographics were assessed } \\
\text { by questionnaires }\end{array}$ & $\begin{array}{l}\text { The quality of life of cervical and } \\
\text { endometrial cancer survivors was } \\
\text { close to that of healthy controls by } \\
5 \text { years post-diagnosis. However, the } \\
\text { cervical cancer survivors reported } \\
\text { more negative mood than the } \\
\text { endometrial cancer survivors or } \\
\text { healthy controls. Cancer survivors } \\
\text { who are unemployed or living alone } \\
\text { may be especially at risk for mood and } \\
\text { mental health difficulties }\end{array}$ \\
\hline $\begin{array}{l}\text { Bodurka-Bevers } \\
\text { et } \mathrm{al}^{37}\end{array}$ & 2000 & $\begin{array}{l}\text { Depression, anxiety, and } \\
\text { quality of life in patients } \\
\text { with epithelial ovarian } \\
\text { cancer }\end{array}$ & $\begin{array}{l}\text { Prospective, } \\
\text { cross-sectional }\end{array}$ & $\begin{array}{l}\text { Questionnaires (CES-D, } \\
\text { State Anxiety Subscale of the } \\
\text { Spielberger State-Trait } \\
\text { Anxiety Inventory, Zubrod } \\
\text { score) }\end{array}$ & $\begin{array}{l}\text { Clinically significant depression and } \\
\text { anxiety may be more prevalent in } \\
\text { patients with EOC than previously } \\
\text { reported }\end{array}$ \\
\hline Fowler et $\mathrm{al}^{38}$ & 2004 & $\begin{array}{l}\text { The gynecologic oncology } \\
\text { consult: symptom } \\
\text { presentation and } \\
\text { concurrent symptoms of } \\
\text { depression and anxiety }\end{array}$ & $\begin{array}{l}\text { Prospective, } \\
\text { cross-sectional }\end{array}$ & $\begin{array}{l}\text { Measures assessing depression } \\
\text { (Center for Epidemiological } \\
\text { Studies Depression Scale) } \\
\text { and anxiety (Beck Anxiety } \\
\text { Inventory) symptoms, common } \\
\text { gynecologic signs/symptoms } \\
\text { and sociodemographic } \\
\text { characteristics }\end{array}$ & $\begin{array}{l}\text { Reports of clinically significant } \\
\text { depressive ( } 42 \%) \text { and anxiety symptoms } \\
(30 \%) \text { were high. The number of } \\
\text { gynecologic symptoms was reliably } \\
\text { correlated with emotional distress. } \\
\text { Age and absence of a partner may have } \\
\text { conferred added vulnerability. For } \\
\text { the women with partners, lengthier } \\
\text { relationships appeared to offer } \\
\text { protection against both depressive and } \\
\text { anxiety symptoms }\end{array}$ \\
\hline $\begin{array}{l}\text { Hengrasmee } \\
\text { et } \mathrm{al}^{39}\end{array}$ & 2004 & $\begin{array}{l}\text { Depression among } \\
\text { gynecologic cancer } \\
\text { patients at Siriraj Hospital: } \\
\text { prevalence and associated } \\
\text { factors }\end{array}$ & $\begin{array}{l}\text { Prospective, } \\
\text { cross-sectional }\end{array}$ & HRSR-questionnaire & $\begin{array}{l}\text { Depression is one of the most common } \\
\text { psychological disorders experienced } \\
\text { by cancer patients. The prevalence of } \\
\text { depression among gynecologic cancer } \\
\text { patients at Siriraj Hospital was as high } \\
\text { as } 13.4 \% \text {. Risk factors included low } \\
\text { income, diagnosis of cervical cancer, } \\
\text { radiation treatment regimen, and poor } \\
\text { performance status }\end{array}$ \\
\hline $\begin{array}{l}\text { Distefano } \\
\text { et } \mathrm{al}^{45}\end{array}$ & 2008 & $\begin{array}{l}\text { Quality of life and } \\
\text { psychological distress } \\
\text { in locally advanced } \\
\text { cervical cancer patients } \\
\text { administered preoperative } \\
\text { chemoradiotherapy }\end{array}$ & $\begin{array}{l}\text { Prospective, } \\
\text { cross-sectional }\end{array}$ & $\begin{array}{l}\text { SF-36 questionnaire on general } \\
\text { health and HADS questionnaire } \\
\text { on mental distress }\end{array}$ & $\begin{array}{l}\text { Locally advanced cervical cancer } \\
\text { patients administered preoperative } \\
\text { chemoradiation showed quality of } \\
\text { life scores comparable to those of } \\
\text { EEC (early-stage disease) patients } \\
\text { and a higher proportion of anxiety } \\
\text { disorders; a low educational level and } \\
\text { unemployment status were mainly } \\
\text { associated with poor quality of life } \\
\text { scores }\end{array}$ \\
\hline
\end{tabular}


Table I (Continued)

\begin{tabular}{|c|c|c|c|c|c|}
\hline Authors & Year & Question & Design & Methods & Results \\
\hline Telepak et al ${ }^{46}$ & 2014 & $\begin{array}{l}\text { Psychosocial factors and } \\
\text { mortality in women with } \\
\text { early stage endometrial } \\
\text { cancer }\end{array}$ & $\begin{array}{l}\text { Prospective, } \\
\text { cross-sectional }\end{array}$ & $\begin{array}{l}\text { Participants provided } \\
\text { psychosocial data immediately } \\
\text { prior to surgery, and survival } \\
\text { statuses } 4-5 \text { years post- } \\
\text { diagnosis were abstracted via } \\
\text { medical record review }\end{array}$ & $\begin{array}{l}\text { Adjusting for age, presence of regional } \\
\text { disease, and medical comorbidity } \\
\text { severity (known biomedical prognostic } \\
\text { factors), greater use of an active coping } \\
\text { style prior to surgery was significantly } \\
\text { associated with a lower probability of } \\
\text { all-cause mortality; life stress, depressive } \\
\text { symptoms, use of self-distraction } \\
\text { coping, receipt of emotional support } \\
\text { and endometrial cancer quality of life } \\
\text { prior to surgery were not significantly } \\
\text { associated with all-cause mortality } \\
4-5 \text { years following diagnosis }\end{array}$ \\
\hline $\begin{array}{l}\text { Ashing-Giwa } \\
\text { et } \mathrm{al}^{48}\end{array}$ & 2009 & $\begin{array}{l}\text { Cervical cancer } \\
\text { survivorship in a } \\
\text { population based sample }\end{array}$ & $\begin{array}{l}\text { Prospective, } \\
\text { cross-sectional }\end{array}$ & $\begin{array}{l}\text { A cross-sectional design with } \\
\text { a population-based sample } \\
\text { ascertained from the California } \\
\text { Cancer Surveillance Program. } \\
\text { Descriptive, bivariate, and } \\
\text { multivariate regression analyses } \\
\text { were conducted }\end{array}$ & $\begin{array}{l}\text { These cervical cancer survivors } \\
\text { reported poor-to-moderate HRQOL } \\
\text { with persistent psychosocial challenges. } \\
\text { The findings indicate that lower SES, } \\
\text { monolingual Latinas are at the greatest } \\
\text { risk of poor HRQOL outcomes }\end{array}$ \\
\hline Ye et $\mathrm{al}^{47}$ & 2014 & $\begin{array}{l}\text { A systematic review of } \\
\text { quality of life and sexual } \\
\text { function of patients with } \\
\text { cervical cancer after } \\
\text { treatment }\end{array}$ & Review & $\begin{array}{l}\text { Studies from an electronic } \\
\text { database conducted between } \\
\text { May } 1966 \text { and May } 2013 \text { were } \\
\text { rated on their internal validity } \\
\text { for methodological assessment. } \\
\text { Thirty-two studies were } \\
\text { included, of which I5 had a } \\
\text { relatively good methodology }\end{array}$ & $\begin{array}{l}\text { The studies showed that quality of } \\
\text { life and sexual function in CCSs were } \\
\text { compromised to different extents } \\
\text { compared with the general population. } \\
\text { More attention should be paid to } \\
\text { quality of life and sexual function after } \\
\text { treatment in patients with cervical } \\
\text { cancer }\end{array}$ \\
\hline $\begin{array}{l}\text { Petersen and } \\
\text { Quinlivan }{ }^{51}\end{array}$ & 2002 & $\begin{array}{l}\text { Preventing anxiety } \\
\text { and depression in } \\
\text { gynecological cancer }\end{array}$ & $\mathrm{RCT}$ & $\begin{array}{l}\text { Patients were randomized to a } \\
\text { control or intervention group } \\
\text { and completed the HADS and } \\
\text { GHQ-28 questionnaires }\end{array}$ & $\begin{array}{l}\text { The intervention was associated with } \\
\text { significant reductions in both scores }\end{array}$ \\
\hline
\end{tabular}

Abbreviations: CCS-Comparative Candidates Survey; CES-D-Center for Epidemiologic Studies Depression Questionnaire, German Version; EEC-emotional expressing questionnaire; EOC-emotion orientated coping; EORTC-European Association for Research and treatment of Cancer; GHQ-28, General Health Questionnaire-28; HADS, Hospital Anxiety and Depression Scale; HRQOL, health-related quality of life; HRSR-Health-related self-report; QLQ-Quality of Life Questionnaire; RCT, randomized controlled trial; SCID, structured clinical interview for DSM IV; SES-Sexual Excitation scale; SF-36 quality of Life assessment.

Scale (HADS), which is a screening test for mild forms of psychiatric disorders, and conducted further interviews on self-esteem/self-confidence and self-perception of physical attractiveness. The HADS showed that $41 \%$ of the women were either doubtful (with a cut-off of 8 points) or definite (with a cut-off of 11 points) cases.

Similar results were demonstrated by Kim et al using the same questionnaire (eg, the authors showed a prevalence of anxiety of $39.5 \%$ and a prevalence of depression of $34.6 \%) .{ }^{31}$ The highest prevalence of depression and anxiety disorders was reported by Yang et al (HADS, prevalence $52.2 \%){ }^{32}$

Klee et al, ${ }^{33}$ observed a sample over time (up to 24 months) using the Center for Epidemiologic Studies Depression Scale and the Profile of Mood States questionnaires and found a decrease after 6 months from the initially high scores for depression and worry to the lower scores of the control group. Bradley et al conducted a follow-up over 5 years and showed the same results.

Other studies used other questionnaires (Spielberger State Trait Anxiety Inventory, Beck Depression Inventory) but obtained the same results (Cull et al [33\% prevalence of depression] and Lau et al [37\% prevalence of depression and anxiety])..$^{35,36}$

Concerning comorbid anxiety and depression, high proportions were demonstrated as well (45.5\% prevalence of comorbidity in Yang et $\mathrm{al}^{32}$ and $33 \%$ in Lau et $\mathrm{al}^{36}$ ).

When examining other gynecologic cancers such as ovarian cancer, Bodurka-Bevers et $\mathrm{al}^{37}$ found a $21 \%$ prevalence of depression and a $29 \%$ prevalence of anxiety in 2000. In 2004, Fowler et al examined gynecologic cancer patients (not specifically defined) from a national cancer 
Table 2 Psychiatric disorders in a population with gynecologic cancer recurrence

\begin{tabular}{|c|c|c|c|c|c|c|}
\hline Authors & Year & Question & $\begin{array}{l}\text { No of } \\
\text { patients }\end{array}$ & Design & Methods & Results \\
\hline Thornton et $\mathrm{al}^{52}$ & 2014 & $\begin{array}{l}\text { Emotions and social } \\
\text { relationships for breast } \\
\text { and gynecologic cancer } \\
\text { patients: coping with } \\
\text { recurrence }\end{array}$ & 35 & Qualitative & $\begin{array}{l}\text { Individuals receiving follow-up } \\
\text { care for recurrent breast or } \\
\text { gynecologic cancer participated in } \\
\text { an individual or a group interview; } \\
\text { transcripts of interviews were } \\
\text { analyzed using a coding form with } \\
\text { two areas of emphasis. }\end{array}$ & $\begin{array}{l}\text { Patients identified notable } \\
\text { differences in their initial } \\
\text { responses to the diagnosis } \\
\text { of cancer and their current } \\
\text { responses to recurrence. }\end{array}$ \\
\hline Thornton et $\mathrm{al}^{53}$ & 2014 & $\begin{array}{l}\text { Test of mindfulness } \\
\text { and hope components } \\
\text { in a psychological } \\
\text { intervention for women } \\
\text { with cancer recurrence }\end{array}$ & 32 & Prospective & $\begin{array}{l}\text { Patients with recurrent breast } \\
\text { or gynecologic cancer received } \\
20 \text { treatment sessions in an } \\
\text { individual ( } \mathrm{n}=12 \text { ) or group ( } \mathrm{n}=20 \text { ) } \\
\text { format; independent variables } \\
\text { (eg, hope and mindfulness) and } \\
\text { psychological outcomes (eg, } \\
\text { depression, negative mood, } \\
\text { worry, and symptoms of } \\
\text { generalized anxiety disorder) } \\
\text { were assessed pretreatment } \\
\text { and after } 2,4 \text {, and } 7 \text { months; } \\
\text { measures of session-by-session } \\
\text { therapy process (positive and } \\
\text { negative affect and quality of } \\
\text { life) and mechanism (use of } \\
\text { intervention-specific skills) were } \\
\text { also included. }\end{array}$ & $\begin{array}{l}\text { Distress, anxiety, and } \\
\text { negative affect decreased, } \\
\text { whereas positive affect } \\
\text { and mental health-related } \\
\text { quality of life increased } \\
\text { over the course of } \\
\text { treatment, as demonstrated } \\
\text { using mixed-effects models } \\
\text { with the intent-to-treat } \\
\text { sample. Both hope and } \\
\text { mindfulness increased, and } \\
\text { use of mindfulness skills } \\
\text { was related to decreased } \\
\text { anxiety. }\end{array}$ \\
\hline
\end{tabular}

institute and showed a $42 \%$ prevalence of depression and a $30 \%$ prevalence of anxiety. ${ }^{38}$

The only study with lower values for the prevalence of depression was conducted by Hengrasmee et al. ${ }^{39}$ These authors found a prevalence of depression in gynecologic cancer patients of $13.4 \%$, which is lower than the lifetime prevalence of depression in the general population of $16 \%-20 \% ;{ }^{40-43}$ these authors proposed that the different types of psychological instruments administered (they used the Health-Related Self-Report questionnaire) could have been responsible for the lower results obtained. A study conducted by Jacob et a ${ }^{44}$ also found slightly lower rates of depression and anxiety in genital/cervical cancer patients.

Regarding other components, such as QoL, a study by Distefano et $\mathrm{a}^{45}$ showed that locally advanced cervical cancer patients had lower QoL scores than not only the general population but also patients with ovarian, endometrial, and other cancers. In 2000 , Klee et $\mathrm{al}^{33}$ described the psychological and social reactions of 118 women with advancedstage cervical cancer and found similar results. Regarding coping mechanisms, the patients' coping abilities seemed nearly stable.

Bradley et al ${ }^{34}$ showed that QoL improved over time and did not significantly differ from that of healthy women after 5 years, although cervical cancer survivors more frequently reported a negative mood (dysphoria, anger, and confusion). Comparisons between endometrial and cervical cancer survivors showed that endometrial cancer survivors exhibited better social well-being and social functioning. ${ }^{34}$

Additionally, Corney et a ${ }^{30}$ assessed self-esteem/selfconfidence and self-perception of physical attractiveness in their sample and found that more than half of the women felt the same as before their operations; however, $30 \%-40 \%$ felt that there had been negative changes.

Furthermore, these authors asked the patients about when they had experienced the most distress; this period seemed to coincide with the period of the most uncertainty (between the first medical indication and the diagnosis or between diagnosis and surgery).

Interestingly, life stress, depressive symptoms, and QoL prior to surgery were not associated with all-cause mortality according to Telepak et al. ${ }^{46}$

Finally, Ye et a ${ }^{47}$ obtained similar conclusions in their review concerning the treatment outcome of cervical cancer patients; specifically, QoL and sexual function were reduced in cervical cancer patients compared to the general population and should be treated with higher priority. 


\section{Predictors, associated factors, and prevention strategies}

The examination of the possible predictors and associated factors of attending psychiatric disorders highlighted three factors in particular because of their association with poorer outcomes of cervical cancer patients:

- physical symptoms,

- lower socioeconomic status,

- sexual inactivity.

Each factor was found in four studies to show a significant association with the occurrence of depression, anxiety, or reduced QoL. ${ }^{30,31,34-36,38,39,45}$

More precisely, the most reported physical symptoms were fatigue, gynecologic/menopausal symptoms, and pain. ${ }^{31,35,36,38}$ A lower socioeconomic status implies a low income, potentially unemployment, and a lower education level, which act as risk factors for depression in cancer patients. ${ }^{31,34,39,45}$ In regards to sexual inactivity, Cull et al showed that in their sample of 83 women, 61 were sexually active before the diagnosis, while almost half of the subjects reported deterioration in sexual function after cancer treatment ${ }^{35}$ similar findings were reported in three other publications. . $^{30,31,36}$

Furthermore, one more factor was mentioned by three studies. Fowler et al, ${ }^{38}$ Bradley et al, ${ }^{34}$ and Corney et al ${ }^{30}$ found a link between the absence of a partner or the breakdown of a relationship and the occurrence of psychiatric disease.

Finally, some additional factors seemed to have minor significance but were mentioned nonetheless. These factors included age (younger patients [ $<50$ years] were more likely to be depressed and had a lower QoL than older patients), ${ }^{36,37}$ poor performance status (which quantified cancer patients' general well-being and activities of daily life), ${ }^{37,39}$ history of psychiatric illness, ${ }^{36}$ ethnicity, and language (Spanishspeaking Latinas seemed to be a particularly vulnerable group, potentially due to their socioeconomic status). ${ }^{48}$

Therefore, these factors could be predictors of attending psychiatric disorders; these findings are interesting because they were not specifically identified in general cancer studies ${ }^{49,50}$ but may indicate particularly vulnerable groups.

After analyzing different studies, we found no evidence of a connection between the treatment modality (eg, surgery and radiation) or complications over time (eg, post-operative) and the occurrence of psychiatric disorders, ${ }^{34,35,45}$ this finding is consistent with those of other cancer studies. ${ }^{12,13}$

Yang et $\mathrm{al}^{32}$ found that prevention strategies such as increasing hope, optimism, and general self-efficacy were positive influencing variables. These three variables as a whole showed even stronger predictive value than each one alone, potentially indicating that an integrated measure of multiple variables may be more realistic and effective than an individual construct.

Telepak et $\mathrm{al}^{46}$ found that greater use of active coping prior to surgery was related to a lower probability of allcause mortality; however, it is important to consider that the use of different coping strategies depends on the patient's cultural background, ${ }^{48}$ and thus we cannot specify a certain strategy.

Petersen and Quinlivan ${ }^{51}$ examined the effect of counseling and a relaxation intervention in patients with gynecologic cancer. These authors interviewed patients using the HADS and the General Health Questionnaire-28 and found that the intervention (conscious breathing, body scans, progressive muscle relaxation, and guided imagery) was associated with a significant reduction in the total scores of both questionnaires.

\section{Psychiatric disorders in a population with gynecologic cancer recurrence}

Thornton et $\mathrm{al}^{52}$ conducted a qualitative study of coping with recurrence in breast and gynecologic cancer patients. The patients participated in an individual or a group interview, and the authors observed notable differences in their responses to the initial diagnosis as opposed to the recurrence..$^{52}$ The most important themes discussed were as follows:

- occurrence of depressive symptoms,

- decreased size of social networks (with passing years),

- additional losses from the erosion of social support networks.

In another study, the authors developed a psychological intervention for women with cancer recurrence and assessed independent variables (eg, hope and mindfulness) and psychological outcomes (eg, depression, negative mood, worry, and symptoms of generalized anxiety disorder) pretreatment and after 2, 4, and 7 months..$^{53}$ The results showed that the negative factors (distress, anxiety, and negative affect) decreased, whereas the positive factors (positive affect, mental health-related QoL, hope, and mindfulness) increased over the course of treatment.

To summarize, patients with gynecologic malignancies, such as cancer of the cervix, clearly show an increased risk of attending psychiatric symptoms, mainly depressive mood alterations. The main limitation of this review, which in some aspect is caused by methodology, is that it only included a small number of papers that specifically addressed psychologic impairments other than somatic symptoms. Therefore, 
the cervical cancer population should first be compared to other gynecologic cancer populations using one consistent (prospective) study design, which should compare those diagnosed with ovarian or endometrial cancer to matched patients with breast cancer, as the most common type of cancer in females. The scores should integrate self-reported and interview-based ratings as direct clinical diagnoses to obtain robust results.

Larger sample sizes and comparable results regarding the mentioned impairments are needed in these populations. The prevalence of depression among cervical cancer patients ranges from $33 \%-52 \%$, and this rate among other gynecologic cancer populations is approximately $21 \%$. To interpret these results, it could be useful to consider the following numbers: the prevalence of depression in the general population at any point in the past 12 months is $7.7 \%-17.6 \%,{ }^{54}$ therefore, the rates of depression are at least two times higher in the examined group than in the general population, emphasizing the need for extensive depressive/ anxiety screening in cervical cancer patients. ${ }^{41}$

Regarding QoL, the lowest scores were also reported to occur in the cervical cancer population, ${ }^{45}$ and social well-being and social functioning also seemed to be worse in patients with cervical cancer than in those with other gynecologic cancers. These results indicate that women diagnosed with cervical cancer may be especially vulnerable, eg, due to lifestyle factors associated with the epidemiology of this cancer (younger age, absence of a partner, and lower educational level). This finding supports the need for systematic examinations, as previously discussed in this context. The high rates of comorbid anxiety (anxiety disorder itself and not situation-specific fears) and depression in genital/ cervical cancer patients, ranging from 33\%-45\%, are also much higher than the rates in the normal population (rates reported up to $15 \%) .{ }^{55-57}$

QoL can improve over time in gynecologic cancer patients and increase to that of healthy women; ${ }^{34}$ however, the results indicate significant room for improvement with a variety of therapeutic and psychosocial approaches such as social support and psychological intervention. Effective, validated psychosocial approaches and interventions for other types of cancer are well known. However, only a few studies have addressed the preliminary results on the effects of these interventions in genital/cervical cancer patients, and the current findings cannot be safely interpreted to indicate effectiveness because of the non-comparable intervention types or the therapeutic goals that did not persist in follow-up examinations. $^{58-63}$

\section{Conclusion}

Comorbid patients tend to have severe symptoms, poorer outcomes, and greater use of health care resources than those with a single disorder. Furthermore, these patients have a higher suicidal risk; therefore, it is very important to detect and treat both disorders. ${ }^{64,65}$

Additionally, certain factors have been shown to predict the onset of attending psychiatric disorders. Therefore, certain high-risk patient groups (lower socioeconomic status, sexual inactivity, and/or absence of a partner) are especially in need of screening programs for psychiatric co-therapy. Furthermore, patients in groups classified as high risk, which is a negative predictor of lower psychosocial outcome, should receive special psychological support before an attending psychiatric disorder can occur.

Finally, patients suffering from recurrent gynecologic cancer warrant particular attention because of their reports of increased depressive symptoms, which are much greater compared with the common population ${ }^{1,2}$ and comparable to cancer patients, and of concomitant impairments such as reduced social networks and additional losses from the deterioration of their social support network.

The small number of studies included in this analysis is certainly a major limitation, but the findings provide a foundation for further research in this field.

\section{Recommendation for future research}

Extending the research approaches reported here to other fields, such as attending psychiatric disorders in patients with precursors of gynecologic cancer, is highly recommended.

In the future, more studies are needed concerning the epidemiology, patho-mechanisms, and treatment of different psychiatric disorders in patients with gynecologic cancer, especially in under-recognized patients with genital/cervical cancer. In this context, differentiation between the applied therapeutic and psychosocial interventions is also needed.

Moreover, it would be interesting to explore different coping mechanisms and then assess the regular, systematic coping strategies or interventions in these women. Little research has been conducted concerning the resilience of these patients. Thus, it would be useful to identify the deficits in the resilience structure of patients with gynecologic cancer to offer better support.

Therefore, future research should establish standardized and regular screening programs for psychiatric disorders in gynecologic cancer patients, especially after each genital/ cervical cancer diagnosis, given the limited data concerning psychologic alterations in this group of patients. 
These screening programs should include standardized screening questionnaires distributed regularly by gynecologists after a genital/cervical cancer diagnosis to patients in the specific reported high-risk subgroups (those with imminent depressive symptoms, diminished social networks and social support, physical symptoms concurrent with the disease, sexual inactivity, or low socioeconomic status). Patients who screen positive should be further assessed using a clinical interview to determine whether a psychiatric diagnosis is warranted and, if appropriate, to provide specialized treatment to improve the psychosocial outcome of these patients.

\section{Author contributions}

All authors contributed toward data analysis, drafting and revising the paper and agree to be accountable for all aspects of the work.

\section{Disclosure}

The authors report no conflicts of interest in this work.

\section{References}

1. Alonso J, Angermeyer MC, Bernert S, et al. Prevalence of mental disorders in Europe: results from the European Study of the Epidemiology of Mental Disorders (ESEMeD) project. Acta Psychiatr Scand Suppl. 2004;109(420):21-27.

2. Krebber AM, Buffart LM, Kleijn G, et al. Prevalence of depression in cancer patients: a meta-analysis of diagnostic interviews and self-report instruments. Psychooncology. 2014;23(2):121-130.

3. Meijer A, Roseman M, Milette K, et al. Depression screening and patient outcomes in cancer: a systematic review. PLoS One. 2011; 6(11):e27181.

4. Walker J, Wanat M, Fielding J, Martin P, Petit A, Burke K, Sharpe M. Screening medical patients for depression: lessons from a national program in cancer clinics. Psychosomatics. 2017;58(3):274-280.

5. eco.iarc.fr [homepage on the Internet]. EUCAN Iafroc. Estimated incidence, mortality \& prevalence of breast cancer. IARC. Available from: http://eco.iarc.fr/eucan/CancerOne.aspx?Cancer=46\&Gender=2. Accessed October 1, 2017.

6. Reich M, Lesur A, Perdrizet-Chevallier C. Depression, quality of life and breast cancer: a review of the literature. Breast Cancer Res Treat. 2008; 110(1):9-17.

7. Smith HR. Depression in cancer patients: pathogenesis, implications and treatment (Review). Oncol Lett. 2015;9(4):1509-1514.

8. Singer S, Das-Munshi J, Brahler E. Prevalence of mental health conditions in cancer patients in acute care - a meta-analysis. Ann Oncol. 2010;21(5): 925-930.

9. Warren JL, Mariotto A, Melbert D, Schrag D, Doria-Rose P, Penson D, Yabroff KR. Sensitivity of medicare claims to identify cancer recurrence in elderly colorectal and breast cancer patients. Med Care. 2016; 54(8): e47-e54

10. de Moor JS, Virgo KS, Li C, et al. Access to cancer care and general medical care services among cancer survivors in the United States: an analysis of 2011 medical expenditure panel survey data. Public Health Rep. 2016;131(6):783-790.

11. Miller KD, Siegel RL, Lin CC, et al. Cancer treatment and survivorship statistics, 2016. CA Cancer J Clin. 2016;66(4):271-289.
12. Suppli NP, Johansen C, Christensen J, Kessing LV, Kroman N, Dalton SO. Increased risk for depression after breast cancer: a nationwide population-based cohort study of associated factors in Denmark, 1998-2011. J Clin Oncol. 2014;32(34):3831-3839.

13. Qiu J, Yang M, Chen W, Gao X, Liu S, Shi S, Xie B. Prevalence and correlates of major depressive disorder in breast cancer survivors in Shanghai, China. Psychooncology. 2012;21(12):1331-1337.

14. Champagne AL, Brunault P, Huguet G, et al. Personality disorders, but not cancer severity or treatment type, are risk factors for later generalised anxiety disorder and major depressive disorder in non metastatic breast cancer patients. Psychiatry Res. 2016;236:64-70.

15. Leitlinienprogramm Onkologie der AWMF DKeVuDKeV. Interdisziplinäre S3-Leitlinie für die Diagnostik, Therapie und Nachsorge des Mammakarzinoms. Available from: http://www.awmf.org/ uploads/tx_szleitlinien/032-045OL_k_S3_Brustkrebs_Mammakarzinom_Diagnostik_Therapie_Nachsorge_2012-07.pdf. Accessed November 13, 2016.

16. Singer S, Schwentner L, van Ewijk R, et al. The course of psychiatric co-morbidity in patients with breast cancer - results from the prospective multi-centre BRENDA II study. Psychooncology. 2016;25(5): $590-596$.

17. Pinder KL, Ramirez AJ, Black ME, Richards MA, Gregory WM, Rubens RD. Psychiatric disorder in patients with advanced breast cancer: prevalence and associated factors. Eur J Cancer. 1993;29A(4): 524-527.

18. Passik S, Newman M, Brennan M, Holland J. Psychiatric consultation for women undergoing rehabilitation for upper-extremity lymphedema following breast cancer treatment. J Pain Symptom Manage. 1993;8(4): 226-233.

19. Jacob L, Kalder M, Kostev K. Incidence of depression and anxiety among women newly diagnosed with breast or genital organ cancer in Germany. Psychooncology. Epub 2016 Nov 29.

20. Hawighorst-Knapstein S, Fusshoeller C, Franz C, et al. The impact of treatment for genital cancer on quality of life and body image - results of a prospective longitudinal 10-year study. Gynecol Oncol. 2004;94(2): 398-403.

21. Hughes RR. Anxiety in the woman with genital cancer. South Med J. 1966;59(9):1055-1057.

22. eco.iarc.fr [homepage on the Internet] EUCAN Iafroc. Estimated incidence, mortality \& prevalence of ovarian cancer. IARC. Available from: http://eco.iarc.fr/eucan/CancerOne.aspx?Cancer=27\&Gender=2. Accessed October 1, 2017.

23. eco.iarc.fr [homepage on the Internet] EUCAN Iafroc. Estimated incidence, mortality \& prevalence of cervical cancer. IARC. Available from: http://eco.iarc.fr/eucan/CancerOne.aspx?Cancer=25\&Gender=2. Accessed October 1, 2017.

24. eco.iarc.fr [homepage on the Internet] EUCAN Iafroc. Estimated incidence, mortality \& prevalence of cancer of the corpus uteri. IARC. Available from: http://eco.iarc.fr/eucan/CancerOne.aspx? Cancer=26\&Gender=2. Accessed October 1, 2017.

25. Krams M, Frahm S, Kellner U, Mawrin C. Kurzlehrbuch Pathologie. Vol 1. Stuttgart: Georg Thieme Verlag; 2010.

26. Gätje R, Eberle C, Scholz C, et al. Kurzlehrbuch Gynäkologie und Geburtshilfe. Vol 1. Stuttgart: Georg Thieme Verlag; 2011.

27. Grange C, Bonal M, Huyghe E, Leguevaque P, Cances-Lauwers V, Motton S. Qualité de vie sexuelle et cancer du col localement avancé. [Sexual function and quality of life in locally advanced cervical cancer]. Gynecol Obstet Fertil. 2013;41(2):116-122. French.

28. Leitlinienprogramm Onkologie (Deutsche Krebsgesellschaft, Deutsche Krebshilfe, AWMF). S3-Leitlinie "Diagnostik, Therapie und Nachsorge der Patientin mit Zervixkarzinom", Kurzversion 1.02014. [National Guideline Programm Oncology (German Oncologic Society, AWMF). S- $\S$ Guideline 'Diagnoses, Therapy and After-Care of patients with carcinoma of the cervix uteri', shortversion 1.02014.]

29. Bottomley A. Depression in cancer patients: a literature review. Eur $J$ Cancer Care (Engl). 1998;7(3):181-191. 
30. Corney RH, Everett H, Howells A, Crowther ME. Psychosocial adjustment following major gynaecological surgery for carcinoma of the cervix and vulva. $J$ Psychosom Res. 1992;36(6):561-568.

31. Kim SH, Kang S, Kim YM, et al. Prevalence and predictors of anxiety and depression among cervical cancer survivors in Korea. Int J Gynecol Cancer. 2010;20(6):1017-1024.

32. Yang YL, Liu L, Wang XX, Wang Y, Wang L. Prevalence and associated positive psychological variables of depression and anxiety among Chinese cervical cancer patients: a cross-sectional study. PLoS One. 2014;9(4):e94804.

33. Klee M, Thranov I, Machin D. Life after radiotherapy: the psychological and social effects experienced by women treated for advanced stages of cervical cancer. Gynecol Oncol. 2000;76(1):5-13.

34. Bradley S, Rose S, Lutgendorf S, Costanzo E, Anderson B. Quality of life and mental health in cervical and endometrial cancer survivors. Gynecol Oncol. 2006;100(3):479-486.

35. Cull A, Cowie VJ, Farquharson DI, Livingstone JR, Smart GE, Elton RA. Early stage cervical cancer: psychosocial and sexual outcomes of treatment. Br J Cancer. 1993;68(6):1216-1220.

36. Lau KL, Yim PH, Cheung EY. Psychiatric morbidity in Chinese women after cervical cancer treatment in a regional gynaecology clinic. East Asian Arch Psychiatry. 2013;23(4):144-153.

37. Bodurka-Bevers D, Basen-Engquist K, Carmack CL, Fitzgerald MA, Wolf JK, de Moor C, Gershenson DM. Depression, anxiety, and quality of life in patients with epithelial ovarian cancer. Gynecol Oncol. 2000; 78(3 Pt 1):302-308.

38. Fowler JM, Carpenter KM, Gupta P, Golden-Kreutz DM, Andersen BL. The gynecologic oncology consult: symptom presentation and concurrent symptoms of depression and anxiety. Obstet Gynecol. 2004;103(6): 1211-1217.

39. Hengrasmee $P$, Padungsutt $P$, Boriboonhirunsarn D. Depression among gynecologic cancer patients at Siriraj Hospital: prevalence and associated factors. J Med Assoc Thai. 2004;87 Suppl 3:S74-S79.

40. Busch MA, Maske UE, Ryl L, Schlack R, Hapke U. Prävalenz von depressiver Symptomatik und diagnostizierter Depression bei Erwachsenen in Deutschland. Ergebnisse der Studie zur Gesundheit Erwachsener in Deutschland (DEGS1). [Prevalence of depressive symptoms and diagnosed depression within adults in Germany. Findings of the DEGS1-study (mental health in German adults study)] Bundesgesundheitsblatt Gesundheitsforschung Gesundheitsschutz. 2013;56(5-6):733-739. German.

41. Jacobi F, Hofler, M, Strehle J, et al. Psychische Störungen in der Allgemeinbevölkerung - Studie zur Gesundheit Erwachsener in Deutschland und ihr Zusatzmodul Psychische Gesundheit (DEGS1-MH). [Psychiatric diseases within the common population-study on mental health in adults with the additional module (DEGS1-MH)] Der Nervenarzt. 2014;85(1):77-87. German.

42. Kessler RC. Epidemiology of women and depression. J Affect Disord. 2003;74(1):5-13.

43. Kühner C. Gender differences in unipolar depression: an update of epidemiological findings and possible explanations. Acta Psychiatr Scand. 2003;108(3):163-174.

44. Jacob L, Bleicher L, Kostev K, Kalder M. Prevalence of depression, anxiety and their risk factors in German women with breast cancer in general and gynecological practices. J Cancer Res Clin Oncol. 2016;142(2): $447-452$.

45. Distefano M, Riccardi S, Capelli G, et al. Quality of life and psychological distress in locally advanced cervical cancer patients administered pre-operative chemoradiotherapy. Gynecol Oncol. 2008;111(1): 144-150.

46. Telepak LC, Jensen SE, Dodd SM, Morgan LS, Pereira DB. Psychosocial factors and mortality in women with early stage endometrial cancer. Br J Health Psychol. 2014;19(4):737-750.

47. Ye S, Yang J, Cao D, Lang J, Shen K. A systematic review of quality of life and sexual function of patients with cervical cancer after treatment. Int J Gynecol Cancer. 2014;24(7):1146-1157.
48. Ashing-Giwa KT, Tejero JS, Kim J, Padilla GV, Kagawa-Singer M, Tucker MB, Lim JW. Cervical cancer survivorship in a population based sample. Gynecol Oncol. 2009;112(2):358-364.

49. Krauss O, Ernst J, Kuchenbecker D, Hinz A, Schwarz R. Prädiktoren psychischer Störungen bei Tumorpatienten: empirische Befunde. [Predictors of mental disorders in patients with malignant diseases: empirical results]. Psychother Psychosom Med Psychol. 2007; 57(7):273-280. German.

50. Spencer R, Nilsson M, Wright A, Pirl W, Prigerson H. Anxiety disorders in advanced cancer patients: correlates and predictors of end-of-life outcomes. Cancer. 2010;116(7):1810-1819.

51. Petersen RW, Quinlivan JA. Preventing anxiety and depression in gynaecological cancer: a randomised controlled trial. BJOG. 2002; 109(4):386-394.

52. Thornton LM, Levin AO, Dorfman CS, Godiwala N, Heitzmann C, Andersen BL. Emotions and social relationships for breast and gynecologic patients: a qualitative study of coping with recurrence. Psychooncology. 2014;23(4):382-389.

53. Thornton LM, Cheavens JS, Heitzmann CA, Dorfman CS, Wu SM, Andersen BL. Test of mindfulness and hope components in a psychological intervention for women with cancer recurrence. J Consult Clin Psychol. 2014;82(6):1087-1100.

54. Steel Z, Marnane C, Iranpour C, Chey T, Jackson JW, Patel V, Silove D. The global prevalence of common mental disorders: a systematic review and meta-analysis 1980-2013. Int J Epidemiol. 2014;43(2):476-493.

55. Cooney LG, Lee I, Sammel MD, Dokras A. High prevalence of moderate and severe depressive and anxiety symptoms in polycystic ovary syndrome: a systematic review and meta-analysis. Hum Reprod. 2017;32(5):1075-1091.

56. Mehta RD, Roth AJ. Psychiatric considerations in the oncology setting. CA Cancer J Clin. 2015;65(4):300-314.

57. Ohayon MM, Shapiro CM, Kennedy SH. Differentiating DSM-IV anxiety and depressive disorders in the general population: comorbidity and treatment consequences. Can J Psychiatry. 2000;45(2):166-172.

58. Ngu SF, Wei N, Kwan TT, Chu MM, Tse KY, Chan KK, Ngan HY. Impact of different educational interventions on psychosocial well-being of women with a positive high-risk human papillomavirus and normal cervical cytology: a randomised trial. J Psychosom Obstet Gynaecol. 2017:1-10.

59. Moug SJ, Bryce A, Mutrie N, Anderson AS. Lifestyle interventions are feasible in patients with colorectal cancer with potential shortterm health benefits: a systematic review. Int J Colorectal Dis. 2017; 32(6):765-775.

60. Leclerc AF, Foidart-Dessalle M, Tomasella M, et al. Multidisciplinary rehabilitation program after breast cancer: benefits on physical function, anthropometry and quality of life. Eur J Phys Rehabil Med. Epub 2017 Mar 20.

61. Li P, Huang J, Wu H, Fu C, Li Y, Qiu J. Impact of lifestyle and psychological stress on the development of early onset breast cancer. Medicine (Baltimore). 2016;95(50):e5529.

62. Maheu C, Lebel S, Courbasson C, et al. Protocol of a randomized controlled trial of the fear of recurrence therapy (FORT) intervention for women with breast or gynecological cancer. BMC Cancer. 2016; 16:291.

63. Tomei C, Lebel S, Maheu C, Mutsaers B. Addressing fear of recurrence: improving psychological care in cancer survivors. Support Care Cancer. 2016;24(7):2815-2818.

64. Hirschfeld RM. The comorbidity of major depression and anxiety disorders: recognition and management in primary care. Prim Care Companion J Clin Psychiatry. 2001;3(6):244-254.

65. Pfeiffer PN, Ganoczy D, Ilgen M, Zivin K, Valenstein M. Comorbid anxiety as a suicide risk factor among depressed veterans. Depress Anxiety. 2009;26(8):752-757. 
International Journal of Women's Health

Dovepress

\section{Publish your work in this journal}

The International Journal of Women's Health is an international, peerreviewed open-access journal publishing original research, reports, editorials, reviews and commentaries on all aspects of women's healthcare including gynecology, obstetrics, and breast cancer. The manuscript management system is completely online and includes

Submit your manuscript here: http://www.dovepress.com/international-journal-of-womens-health-journa a very quick and fair peer-review system, which is all easy to use. Visit http://www.dovepress.com/testimonials.php to read real quotes from published authors. 